\title{
Effects of Chloramphenicol on Post-mortem Biochemical Changes in Scallop Adductor Muscle $^{\dagger}$
}

\author{
Kaoru Kawashima*1 and Hideaki Yamanaka*2 \\ ${ }^{* 1}$ Food Science Laboratory, Faculty of Education, Saitama University, Shimo-okubo, Urawa, Saitama 338, Japan \\ ${ }^{* 2}$ Department of Food Science and Technology, Tokyo University of Fisheries, Konan, Minato, Tokyo 108, Japan \\ (Received December 22, 1993)
}

To clarify the role of endogenous enzymes and bacterial enzymes on post-mortem biochemical changes in scallop adductor muscle, the effects of chloramphenicol (CP) on these changes during storage at 5 and $10^{\circ} \mathrm{C}$ were investigated.

Both muscle with and without $\mathrm{CP}$ added showed the same ATP breakdown pattern; degradation to inosine $(\mathrm{HxR})$ and hypoxanthine $(\mathrm{Hx})$ was not inhibited by $\mathrm{CP}$, therefore, degradation to $\mathrm{HxR}$ and Hx was mainly caused by endogenous enzymes. D-Lactic acid, an end product of glycolysis, increased to a certain level in both muscle with $C P$ and muscle without $C P$ in the early stage of storage. The acid level then remained constant in the muscle with $\mathrm{CP}$, but increased markedly as decomposition progressed in the muscle without CP. D-Lactic acid thus forms due to both endogenous and exogenous enzymes. The final content of octopine, another end product of glycolysis, was higher in the muscle with CP than in the muscle without $\mathrm{CP}$, and this difference is thought to be caused by D-lactic acid formation in the muscle without $\mathrm{CP}$.

Key words: scallop, chloramphenicol, octopine, ATP-related compounds, D-lactic acid, postmortem changes

Post-mortem biochemical changes in invertebrates are known to be different from those in vertebrates, ${ }^{1-3)}$ but no detailed information is available. In the previous report, ${ }^{4}$ the authors showed that the post-mortem biochemical changes in scallop adductor muscle differed markedly from those in fishes ${ }^{5,6)}$ and prawn $^{7}$; decomposition progressed faster at higher storage temperatures, though the decrease in ATP and the increases in inosine (HxR) and hypoxanthine $(\mathrm{Hx})$ were faster at lower storage temperatures, consequently the $\mathrm{K}$ value increased faster at lower storage temperatures. D-Lactic acid, not L-lactic acid, was detected, and while decomposition progressed it accumulated as a possible end product of the post-mortem biochemical changes in scallop adductor muscle together with octopine.

In this report, to clarify the role of endogenous enzymes and bacterial enzymes in the post-mortem biochemical changes of scallop adductor muscle, the effects of antibiotic chloramphenical on these changes were investigated.

\section{Materials and Methods}

\section{Materials}

Live scallop Patinopecten yessoensis was obtained from Tokyo Central Wholesale Market in May 1993. The striated part of the adductor muscle was chopped into small pieces and made into composite samples. Composite samples were divided into 4 portions, and $0.1 \%$ chloramphenicol (CP) was added to 2 portions. Samples with and without $\mathrm{CP}$ were then stored at $5^{\circ} \mathrm{C}$ and $10^{\circ} \mathrm{C}$. At regular intervals, muscle was withdrawn from each portion and subjected to the following tests.

\section{Sensory Evaluation}

The degree of freshness of scallop adductor muscle was evaluated by trained sensory panels and classified into three stages mainly based on its odor: acceptable (no smell), initial decomposition (faintly putrid smell), and advanced decomposition (putrid smell).

\section{Preperation of Extract}

About $5 \mathrm{~g}$ of muscle was homogenized in $20 \mathrm{~m} l$ ice-cold $6 \%$ perchloric acid and the suspension was centrifuged at $10,000 \mathrm{rpm}$ for $10 \mathrm{~min}$. The procedure was repeated and the supernatants were combined. After neutralization with $\mathrm{KOH}$ aqueous solution, the supernatant was made up to $50 \mathrm{~m} /$ with distilled water. This solution was analyzed for ATP, ATPrelated compounds, octopine, arginine, and lactic acid.

\section{Determination of ATP and Its Related Compounds}

The contents of ATP and its related compounds were analyzed by HPLC using the method previously described. ${ }^{4}$

\section{Determination of Octopine and Arginine}

Octopine and arginine were converted to fluorescent derivatives with benzoin, then analyzed by HPLC using the method previously described ${ }^{4)}$

Determination of Lactic Acid

$\mathrm{L}$ - and $\mathrm{D}$-Lactic acids were analyzed using $\mathrm{L}$-lactate dehydrogenase (EC 1.1.1.27, Boehringer Mannheim Co.) and D-lactate dehydrogenase (EC 1.1.1.28, Boehringer Mannheim Co.), respectively, according to the method of Noll. ${ }^{8)}$

\section{Measurement of $p H$ Value}

Two grams of chopped muscle were homogenized in $20 \mathrm{~m} /$ deionized water, then the $\mathrm{pH}$ value of homogenate was measured with a Horiba F-12 pH meter.

\section{Results}

\section{Sensory Evaluation}

Portions of chopped scallop adductor muscle without CP were judged to be at the stage of initial decomposition on

\footnotetext{
$\uparrow$ This studv was presented at the annual meeting of the Japanese Society of Scientific Fisheries, Nagasaki, October, 1993.
} 


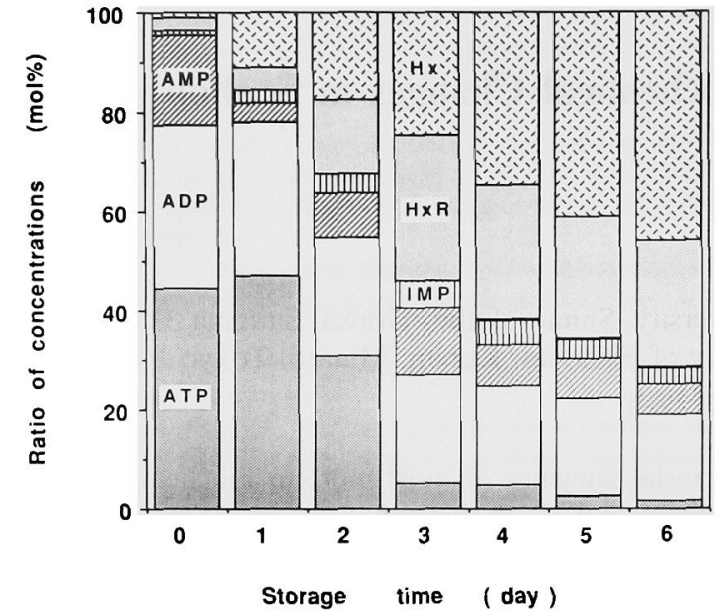

Fig. 1. Changes in ATP and its related compounds in chopped scallop adductor muscle during storage at $5^{\circ} \mathrm{C}$.

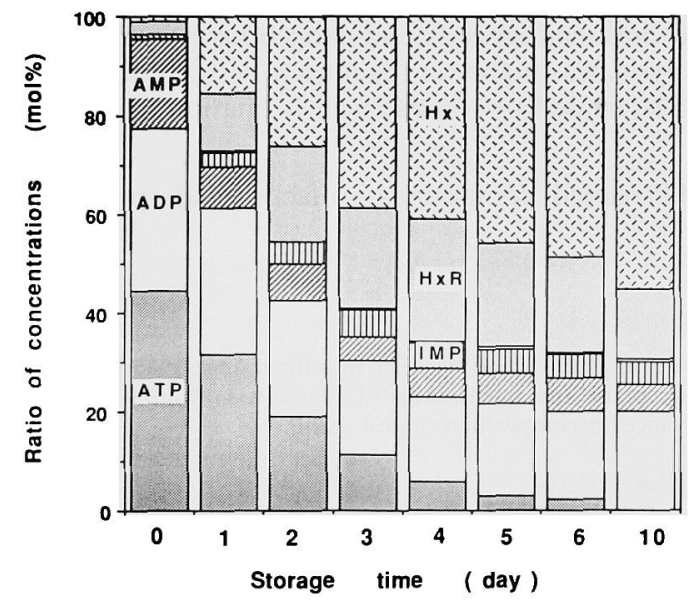

Fig. 2. Changes in ATP and its related compounds in chopped scallop adductor muscle with added chloramphenicol during storage at $5^{\circ} \mathrm{C}$.

the $2 \mathrm{nd}$ day of storage at $10^{\circ} \mathrm{C}$, or on the $3 \mathrm{rd}$ day of storage at $5^{\circ} \mathrm{C}$, and to be at the stage of advanced decomposition on the $3 \mathrm{rd}$ day of storage at $10^{\circ} \mathrm{C}$ or on the 4 th day of storage at $5^{\circ} \mathrm{C}$. On the contrary, for portions with $\mathrm{CP}$, no evidence of decomposition was detected during storage either at $10^{\circ} \mathrm{C}$ or $5^{\circ} \mathrm{C}$ for 10 days.

\section{ATP and Its Related Compounds}

Figures 1 to 4 show the changes in ATP and its related compounds during storage. Adenosine (AdR) was detected throughout the storage period tested, though in very small quantities (less than $1 \%$ of the total amount of ATP and its related compounds) and showed practically no change. Therefore, AdR does not appear in Figs. 1 to 4 . The total amount of ATP and its related compounds was about $5.4 \mu \mathrm{mol} / \mathrm{g}$ at the start, and remained constant in the portions with $\mathrm{CP}$ during the storage period of 10 days regardless of the storage temperature. However, in the portions without $\mathrm{CP}$, the amount began to decrease as decomposition progressed (after the 6th day at $5^{\circ} \mathrm{C}$ or after the 5 th day at $10^{\circ} \mathrm{C}$ ), falling to about $70 \%$ of the initial value. Even at this highly decomposed stage, xanthine

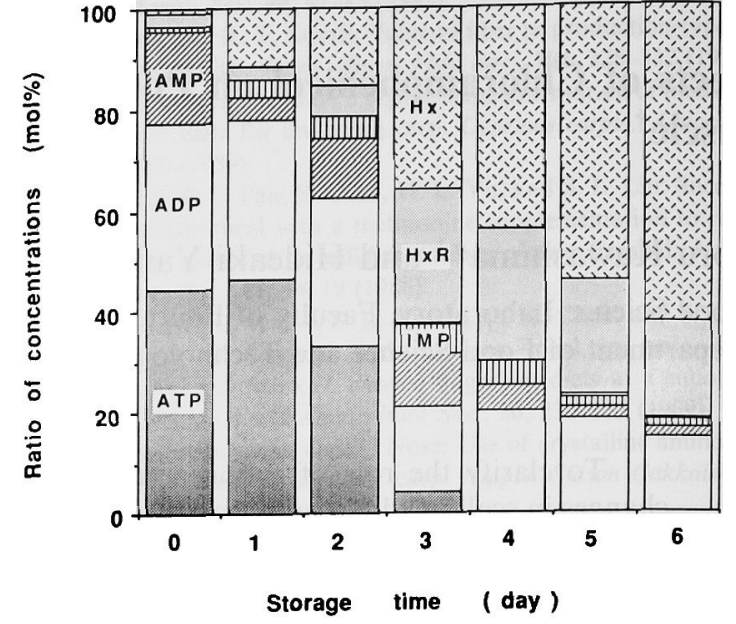

Fig. 3. Changes in ATP and its related compounds in chopped scallop adductor muscle during storage at $10^{\circ} \mathrm{C}$.

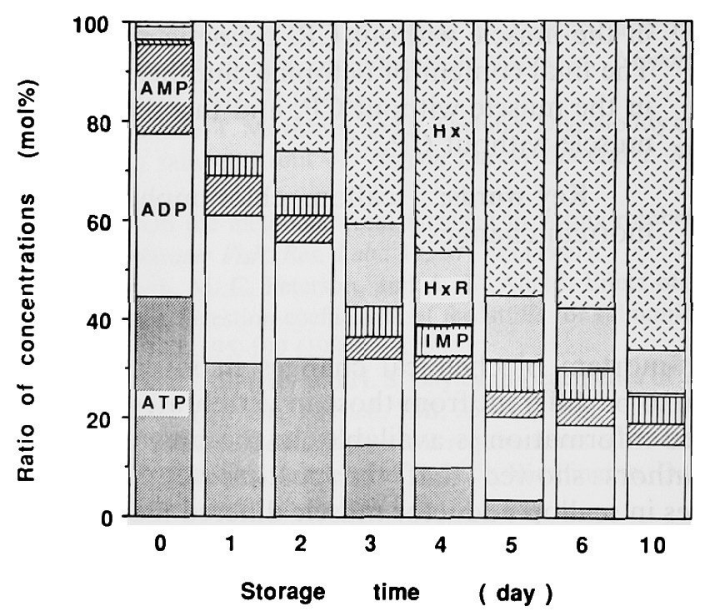

Fig. 4. Changes in ATP and its related compounds in chopped scallop adductor muscle with added chloramphenicol during storage at $10^{\circ} \mathrm{C}$.

production was not observed.

At the beginning, ATP accounted for $45 \%$ of the total amount of ATP-related compounds, ADP 33\%, AMP $18 \%$, IMP $1 \%$, AdR less than $1 \%$, inosine (HxR) $2 \%$, and hypoxanthine (Hx) $1 \%$. ATP gradually decreased during storage in both portions with and without $\mathrm{CP}$, and on the 6 th day of storage it nearly disappeared. With the progress of ATP degradation, HxR slowly accumulated and $\mathrm{Hx}$ accumulated constantly, then HxR began to decrease after 3 to 4 days of storage. Hx accumulation continued, and $\mathrm{Hx}$ accounted for approximately half of the total amount of ATP-related compounds on the 6th day of storage. During the early stage of storage, the rates of accumulation of $\mathrm{HxR}$ and $\mathrm{Hx}$ were higher at $5^{\circ} \mathrm{C}$ than at $10^{\circ} \mathrm{C}$ within both portions with and without $\mathrm{CP}$, then these rates were reversed in the later stage of storage. For portions without $\mathrm{CP}, \mathrm{Hx}$ accumulation accelerated as muscle decomposition fully progressed.

The changes in the $\mathrm{K}$ valve during storage are summarized in Fig. 5. The $\mathrm{K}$ value was $6 \%$ immediately after death, and gradually increased during the first 3 days of storage to around $70 \%$, then remained constant during the 


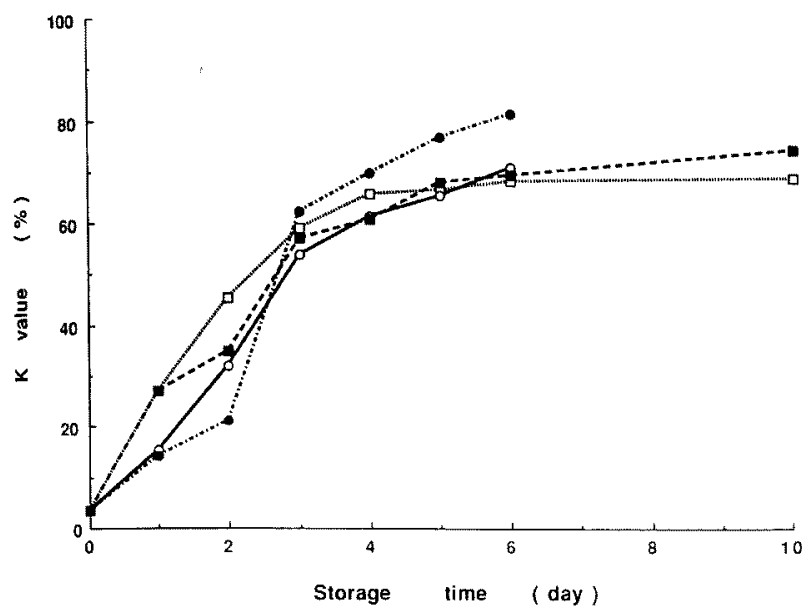

Fig. 5. Effects of chloramphenicol (CP) on changes in the $\mathrm{K}$ value of chopped scallop adductor muscle during storage at 5 and $10^{\circ} \mathrm{C}$.

$\mathrm{O}$, muscle without $\mathrm{CP}$ stored at $5^{\circ} \mathrm{C} ; \mathrm{m}$, muscle without $\mathrm{CP}$ stored at $10^{\circ} \mathrm{C} ; \square$, muscle with $\mathrm{CP}$ stored at $5^{\circ} \mathrm{C}$; muscle with $\mathrm{CP}$ stored at $10^{\circ} \mathrm{C}$.

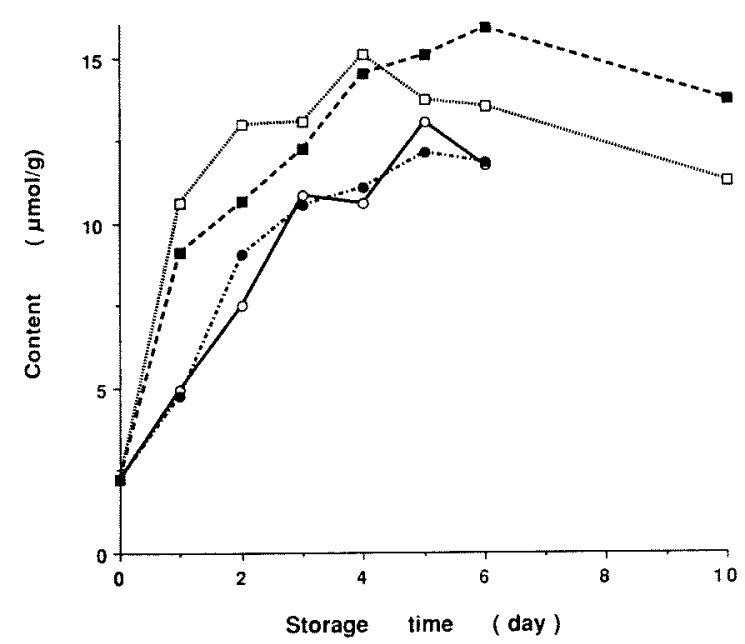

Fig. 6. Effects of chloramphenicol (CP) on changes in octopine in chopped scallop adductor muscle during storage at 5 and $10^{\circ} \mathrm{C}$. Symbols used are the same as Fig. 5.

rest of the storage period with the exception of the portion without $\mathrm{CP}$ stored at $10^{\circ} \mathrm{C}$, in which the $\mathrm{K}$ value increased to nearly $80 \%$ at the end of the storage period.

\section{Octopine and Arginine}

Figure 6 shows the changes in octopine content during storage. Immediately after death, octopine content was $2 \mu \mathrm{mol} / \mathrm{g}$ and increased to $12-16 \mu \mathrm{mol} / \mathrm{g}$ at the end of the storage period. The rate of octopine increase during the early stage of storage was higher at $5^{\circ} \mathrm{C}$ than at $10^{\circ} \mathrm{C}$. Also octopine increased faster in portions with $\mathrm{CP}$ than without, and the final content was larger in portions with $\mathrm{CP}$.

The changes in arginine content during storage are shown in Fig. 7. Arginine content was $7 \mu \mathrm{mol} / \mathrm{g}$ at the start, and gradually decreased during storage to about $2 \mu \mathrm{mol} / \mathrm{g}$. The differences in the changes in arginine content among the 4 portions were fairly small. The arginine content decreased as the octopine content increased.

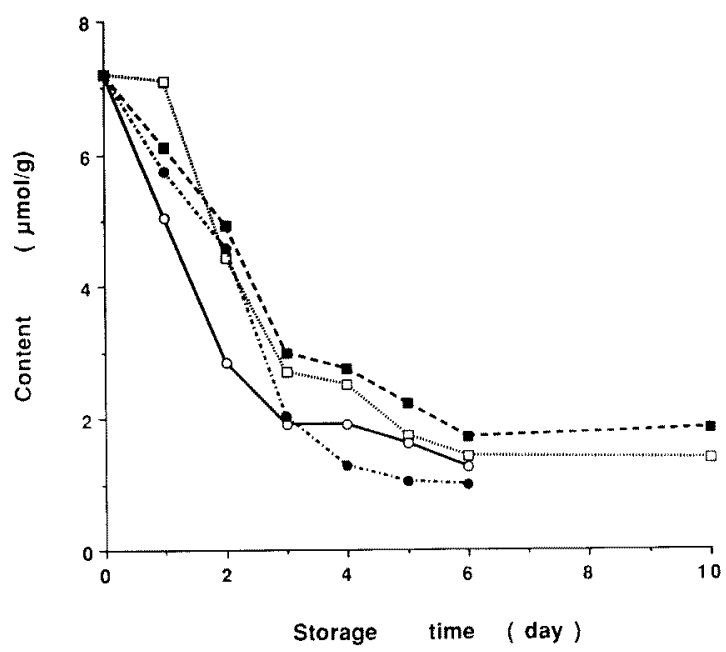

Fig. 7. Effects of chloramphenicol (CP) on changes in arginine in chopped scallop adductor muscle during storage at 5 and $10^{\circ} \mathrm{C}$. Symbols used are the same as Fig. 5 .

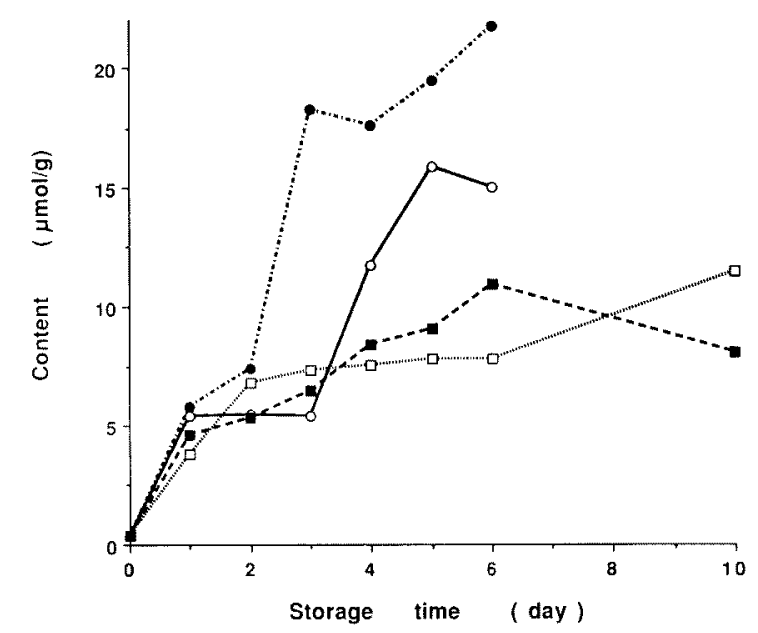

Fig. 8. Effects of chloramphenicol (CP) on changes in D-lactic acid in chopped scallop adductor muscle during storage at 5 and $10^{\circ} \mathrm{C}$. Symbols used are the same as Fig. 5.

\section{Lactic Acid}

Figure 8 shows the changes in D-lactic acid content during storage. Both $\mathrm{L}$-lactic acid and D-lactic acid were detected, but the L-lactic acid content was very small (less than $1 \mu \mathrm{mol} / \mathrm{g}$ ). At the beginning, the D-lactic acid content was less than $1 \mu \mathrm{mol} / \mathrm{g}$, then increased to around $6 \mu \mathrm{mol} / \mathrm{g}$ in the early stage of storage irrespective of the addition of $\mathrm{CP}$. For portions with $\mathrm{CP}$, the content remained constant throughout the rest of the storage period tested, but for portions without $\mathrm{CP}$, it increased further as decomposition progressed, reaching $16 \mu \mathrm{mol} / \mathrm{g}$ for the portion stored at $5^{\circ} \mathrm{C}$ and $25 \mu \mathrm{mol} / \mathrm{g}$ for the portion stored at $10^{\circ} \mathrm{C}$.

\section{pH Value}

The changes in $\mathrm{pH}$ value of scallop adductor muscle during storage are shown in Fig. 9. Muscle $\mathrm{pH}$ immediately after death was 6.89 , gradually decreasing during storage to 6.05 in portions with $\mathrm{CP}$. However, in portions without 


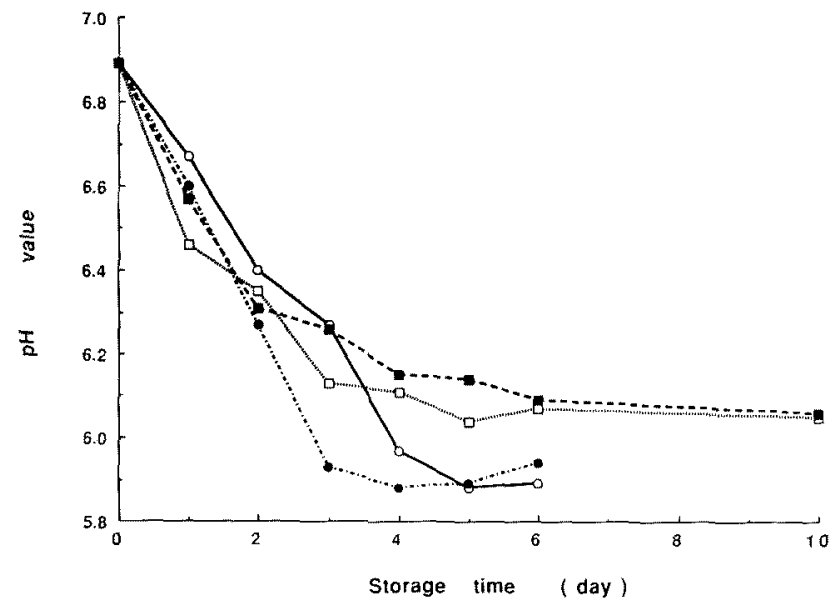

Fig. 9. Effects of chloramphenicol (CP) on changes in $\mathrm{pH}$ value in chopped scallop adductor muscle during storage at 5 and $10^{\circ} \mathrm{C}$. Symbols used are the same as Fig. 5.

$\mathrm{CP}$, muscle $\mathrm{pH}$ rapidly decreased after the onset of decomposition in the muscle, falling to 5.90 .

\section{Discussion}

It is well-known that IMP accumulates as ATP degrada tion progresses in fish muscle, and AMP in molluscs. In the muscle of kuruma prawn, ") ATP degradation resulted in IMP accumulation, and further degradation to $\mathrm{HxR}$ or to $H x$ was very slow, but after muscle reached the stage of initial decomposition, a marked increase in $\mathrm{Hx}$ occurred. But when antibiotic CP was added to muscle, ${ }^{9)}$ degradation to $\mathrm{HxR}$ or to $\mathrm{Hx}$ was completely inhibited, therefore degradation to $\mathrm{HxR}$ or to $\mathrm{Hx}$ is thought to occur by microbial growth.

The same phenomenon was observed for the adductor muscle of Japanese common oyster, in which AMP accumulated instead of IMP. On the contrary, IMP or AMP did not accumulate in scallop adductor muscle, and further degradation to $\mathrm{HxR}$ or to $\mathrm{Hx}$ was rapid. Even when antibiotic $\mathrm{CP}$ was added, $\mathrm{HxR}$ or $\mathrm{Hx}$ formation in scallop adductor muscle was not inhibited. Consequently, in scallop adductor muscle, unlike kuruma prawn muscle or adductor muscle of Japanese common oyster, the accumulation of $\mathrm{HxR}$ and $\mathrm{Hx}$ is thought to be mainly due to endogenous enzymes. Since decomposition to $\mathrm{HxR}$ and $\mathrm{Hx}$ started even in the early stage of storage, and AMP, IMP, and AdR accumulations were very low, this enzymatic activity to form $\mathrm{HxR}$ and $\mathrm{Hx}$ was fairly strong. ADP degradation was slower than A TP degradation, and a fairly large proportion of ADP (around 20\% of the total amount of ATP related compounds) remained even at the end of the storage period, together with large accumulations of degradation products, HxR and $\mathrm{Hx}$. It therefore appears that there is a mechanism which inhibits the conversion of ADP to AMP. Hiltz and Dyer ${ }^{10,11)}$ reported that the increase in $\mathrm{Hx}$ content was linearly related to the decrease in taste of unfrozen or thawed sea scallop Placopecten magellanicus meat. Our results showed that in scallop adductor muscle, the accumulation of $\mathrm{Hx}$ was not affected by bacterial enzymes, but rather by storage tempeature. In order to maintain the quality of scallop adductor muscle, the storage tempeature needs to be chosen carefully.

The $\mathrm{K}$ value, a freshness index defined as the molar ratio of HxR plus Hx to the total of ATP and its related compounds, increased faster at $5^{\circ} \mathrm{C}$ than at $10^{\circ} \mathrm{C}$ during the early stage of storage. The same temperature dependency was observed when scallop adductor muscle was stored at $-3,0$, and $5^{\circ} \mathrm{C}^{4)}$ Similar changes in the $\mathrm{K}$ value were reported for itayagai scallop Pecten albicans adductor muscle ${ }^{12)}$; the $\mathrm{K}$ value increased faster at -3 or $0^{\circ} \mathrm{C}$ than at 5 or $10^{\circ} \mathrm{C}$. Sensory evaluation proved that the higher the storage temperature, the faster the decomposition progressed when stored at 5 and $10^{\circ} \mathrm{C}$, which is the same result when stored at -3 to $5^{\circ} \mathrm{C}$. Thus the $\mathrm{K}$ value cannot be used as a freshness index of scallop adductor muscle within the temperature range of -3 to $10^{\circ} \mathrm{C}$.

Octopine accumulation was higher in portions with $\mathrm{CP}$ than without, while D-lactic acid accumulation in portions without CP was higher than in portions with CP. Since both octopine and D-lactic acid are end products of glycolysis in scallop adductor muscle, the difference in octopine accumulation is partly due to D-lactic acid formation. The rate of octopine accumulation in the early stage of storage was higher in portions with CP than without. Similarly, ATP degradation in the early stage of storage in portions with $\mathrm{CP}$ was slightly faster than in portions without $C P$. The causes of these phenomena are of great interest.

At the beginning of storage, D-lactic acid accumulated regardless of the addition of $\mathrm{CP}$, indicating that D-lactic acid is formed by enzymes in muscle. Then in later stage of storage, D-lactic acid increased rapidly as decomposition progressed in portions without $\mathrm{CP}$, suggesting that D-lactic acid is formed by microbial enzymes at this stage. Therefore, D-lactic acid forms in scallop adductor muscle due to both endogenous muscle enzymes and exogenous bacterial enzymes.

Previously, it was reported that lactate dehydrogenase activity in molluscs was absent or very weak. ${ }^{13-17)}$ Our results showed that $D$-lactic acid was produced both endogenously and exogenously. Previous reports referred to only L-lactate dehydrogenase. It may be possible that scallop adductor muscle contains D-lactate dehydrogenase.

There was little difference in the changes in muscle $\mathrm{pH}$ among the 4 portions in the early stage of storage. Hiltz et al. ${ }^{13)}$ reported that octopine formation was linearly related to the decline in muscle $\mathrm{pH}$ in scallop Placopecten magellanicus muscle, but no evidence of this linear relation was found in our study. The $\mathrm{pH}$ fell rapidly in portions without CP after the onset of decomposition. This rapid decrease is believed to be caused by the increase in D-lactic acid.

\section{References}

1) H. L. Tarr: Post-mortem changes in glycogen, nucleotides, sugar phosphates, and sugars in fish muscles-A review. J. Food Sci., 31 846-854 (1966)

2) T. Saito: Adenosine triphosphate and related compounds in the muscle of aquatic animals. Nippon Suisan Gakkaishi, 27, 461-470 (1961) (in Japanese)

3) A. de Zwaan and T. C. M. Wijsman: Anaerobic metabolism in bivalvia (mollusca) Characteristics of anaerobic metabolism. Comp. Biol. Physiol., 54B, 313-324 (1976). 
4) K. Kawashima and H. Yamanaka: Effects of storage temperatures on the post-mortem biochemical changes in scallop adductor muscle Nippon Suisan Gakkaishi, 58, 2175-2180 (1992).

5) M. Iwamoto, H. Yamanaka, S. Watabe, and K. Hashimoto: Effect of storage temperature on rigor-mortis and ATP degradation in plaice Paralichthys olivaceus muscle. J. Food Sci., 52, 1514-1517 (1987).

6) M. Iwamoto, H. Yamanaka, H. Abe, H. Ushio, S. Watabe, and K. Hashimoto: ATP and creatine phosphate breakdown in spiked plaice muscle during storage, and activities of some enzymes involved. $J$. Food Sci., 53, 1662-1665 (1988).

7) M. Matsumoto and H. Yamanaka: Post-mortem biochemical changes in the muscle of kuruma prawn during storage and evaluation of the freshness. Nippon Suisan Gakkaishi, 56, 1145-1149 (1990).

8) F. Noll: Methods of Enzymatic Analysis, 3rd (ed., ed. by H. U. Bergmeyer), Vol. 6, Verlag Chemie, Weinheim, 1984, pp. 582-588.

9) M. Matsumoto and H. Yamanaka: Influences of antibiotics chloramphenicol on post-mortem biochemical changes in the muscle of kuruma prawn during storage. Nippon Suisan Gakkaishi, 57, 2291-2297 (1991) (in Japanese).

10) D. F. Hiltz and W. J. Dyer: Principal acid-soluble nucleotides in adductor muscle of the scallop (Placopecten maghellanicus) and their degradation during post-mortem storage in ice. J. Fish. Res. Bd. Can., 27, 83-92 (1970).

11) D. F. Hiltz and W. J. Dyer: Hexose monophosphate accumulation and related metabolic changes in unfrozen and thawed adductor muscle of the sea scallop (Placopecten maghellanicus). J. Fish. Res. Bd. Can., 30, 45-52 (1973).

12) M. Iwamoto, H. Yamanaka, S. Watabe, and K. Hashimoto: Changes in ATP and related breakdown compounds in the adductor muscle of "itayagai" scallop Pecten albicans during storage at various temperatures. Nippon Suisan Gakkaishi, 57, 153-156 (1991) (in Japanese).

13) D. F. Hiltz and W. J. Dyer: Octopine in postmortem adductor muscle of the sea ccallop, Placopecten maghellanicus. J. Fish. Res. Bd. Can., 28, 869-874 (1971).

14) G. Gäde and M. K. Grieshaber: Review-Pyruvate reductases catalyze the formation of lactate and opines in anaerobic invertebrates. Comp. Biochem. Physiol, 83B (2), 255-272 (1986).

15) M. Grieshaber and G. Gäde: Energy supply and formation of octopine in the adductor muscle of the scallop, Pecten jacobaeus (Lamarck). Comp. Biochem. Physiol., 58B, 249-252 (1977).

16) T. Shibata: Enzymological studies on the glycolytic system in the muscles of aquatic animals. Mem. Fac. Fish Hokkaido Univ, 24, 1-80 (1977).

17) J. H. Kluytmans, A. M. T. de Bont, J. Jannes, and T. C. M. Wijsman: Time dependent changes and tissue specificities in the accumulation of anaerobic fermentation products in the sea mussel Mytilus edulis. Comp. Biochem. Physiol., 58B, 81-87 (1977). 